\title{
Pulsed Versus Conventional Radio Frequency Ablation for Lumbar Facet Joint Dysfunction
}

\author{
Sanjog Pangarkar $\cdot$ Mark L. Miedema
}

Published online: 16 January 2014

(c) Springer Science+Business Media New York 2014

\begin{abstract}
Low back pain (LBP) is a common source of discomfort and disability. A majority of the US adult population will experience and seek medical attention for the treatment of LBP at some point in their lives. The zygapophysial (facet) joint is a commonly accepted source of LBP and directed interventions exist to address facet-mediated LBP. Hoping to provide longer pain relief, the practice of medial branch denervation utilizing either pulsed or conventional thermal radiofrequency ablation (RFA) can be undertaken. While conventional thermal RFA is widely acknowledged as a viable method to denervate the medial branches for pain relief, pulsed radiofrequency (pRFA) has yet to gain widespread acceptance due to lack of evidence. However, pRFA for facet joint dysfunction may have a role in specific clinical situations.
\end{abstract}

Keywords Lumbar facet joint pain - Zygapophyseal pain . Radiofrequency ablation - Pulsed radiofrequency ablation . Rhizotomy

\section{Introduction}

Low back pain (LBP) is one of the most common reasons adult patients seek medical evaluation in the United States. An epidemiological study by Rubin [1] estimated that

S. Pangarkar

WLA Veterans Administration, Los Angeles, CA, USA

e-mail: sanjog.pangarkar@va.gov

M. L. Miedema ( $\square)$

Physical Medicine and Rehabilitation,

UCLA-WLA VA, 11301 Wilshire Blvd., Los Angeles, CA 90073, USA

e-mail: mmiedema@mednet.ucla.edu between 50 and $80 \%$ of adults will experience at least one episode of back pain during their lifetime. Additionally, LBP is often a frequent cause of disability and dysfunction. In fact, LBP is the leading cause of disability in people younger than 45 years [2]. While the majority of acute LBP episodes will resolve within 3 months, a smaller proportion will go on to develop chronic LBP.

As causality may prove elusive, treatment of chronic LBP is often difficult. LBP can be caused by experiencing traumatic or degenerative disease processes to anatomic structures with somatic innervation [3]. These structures may include the intervertebral disc, sacroiliac joints, lumbar zygapophyseal (facet) joints, bones, nerve roots, ligaments, and muscles [2, 3]. While intervertebral disc pathology is traditionally thought to be the most common source of LBP, lumbar facet joint dysfunction has been estimated to account for 15-45\% of all causes of back pain [2-5]. The emphasis of this review will be to compare two different methods of radiofrequency ablation (RFA) for the treatment of lumbar facet-mediated LBP.

The lumbar facet joints are true synovial joints that provide articulation between adjacent vertebral levels and allow for bending and protection from shear forces [6]. They are made up of the inferior and superior articular processes of adjacent vertebral bodies (Fig. 1). The lumbar facet joints have an arcuate shape with the posterior portion of the joint oriented in an oblique sagittal plane $[6,7]$. Each joint receives dual innervation by the medial branches of the dorsal primary rami from the level above the joint and the level of the joint, for example, the L4-5 facet joint is innervated by L3 and L4 (Fig. 2).

Interventional techniques aimed at treating facet-mediated pain consist of blocking the nociceptive medial branches at their respective levels or intra-articular injection into the joint itself (Fig. 3). While there is limited 
Fig. 1 Oblique view X-ray outlining the fluoroscopic anatomy of the L4-5 facet joint. (Source: Fig. 2 in [32], with kind permission from Springer Science+Business Media)

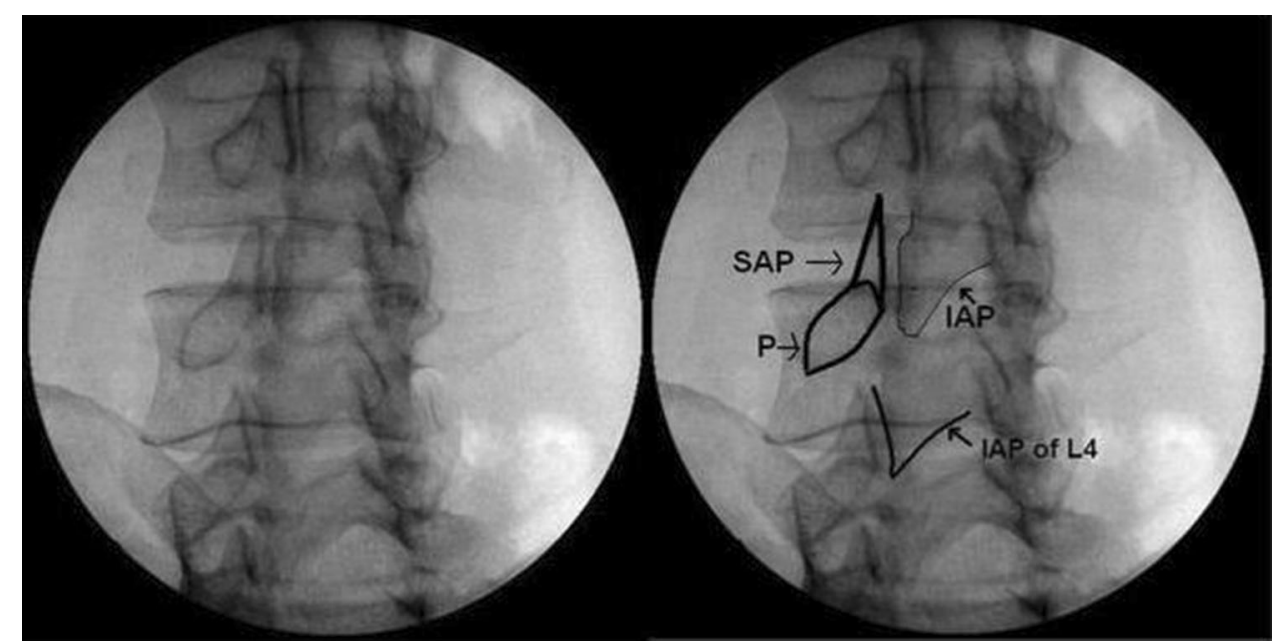

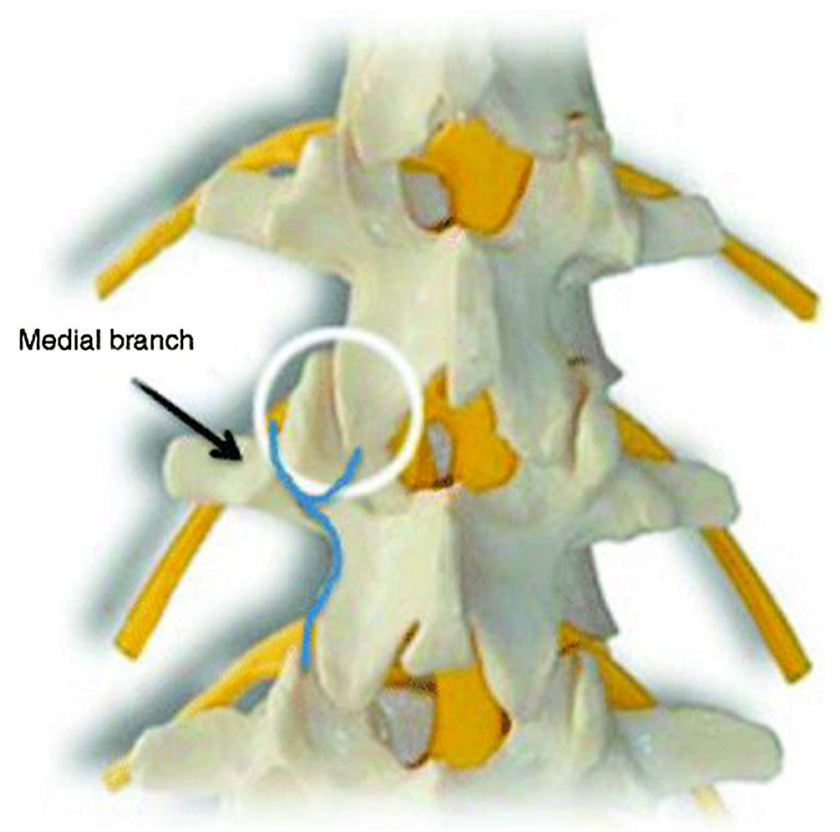

Fig. 2 Posterior view showing the course of the medial branches of the dorsal primary rami as they innervate the facet joint. (Source: Fig. 1 in [33], with kind permission from Springer Science+Business Media)

evidence for the use of intra-articular facet injections, medial branch RFA has shown more favorable outcomes [8]. When pain is satisfactorily relieved with medial branch blocks, RFA of the medial branches can be undertaken in the hope of providing longer lasting effects.

\section{Radiofrequency Ablation}

The first description of fluoroscopic percutaneous RFA to treat spinal facet pain was by Shealy in $1975[9,10]$. While advances in safety and technology have been made, the

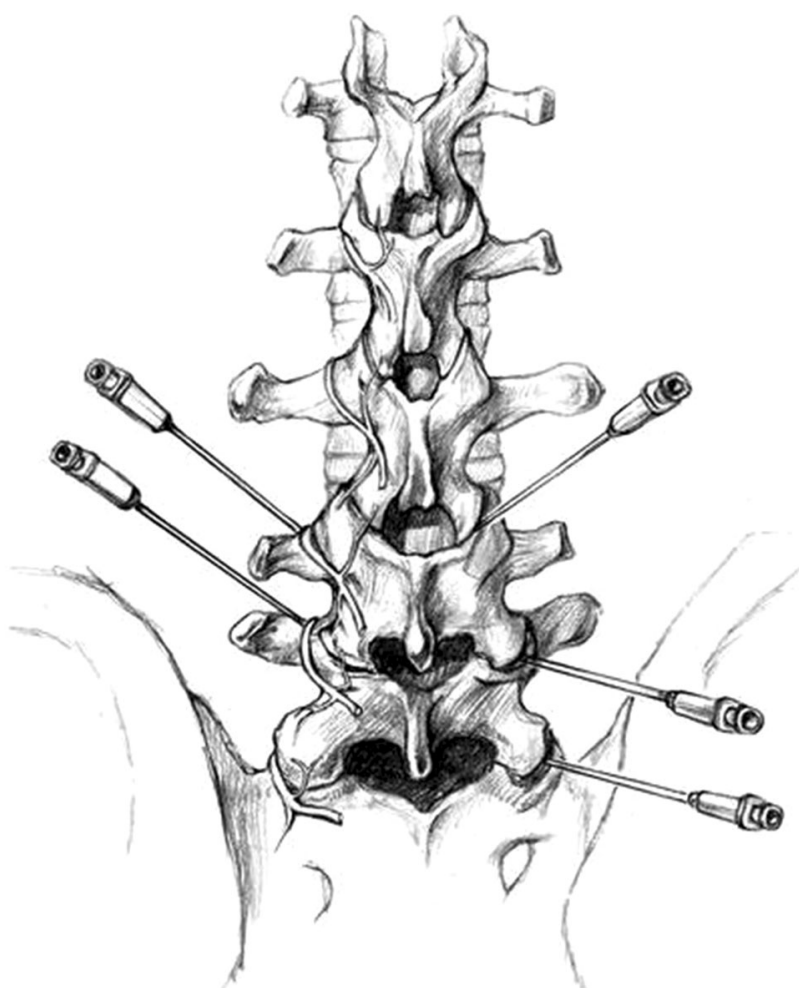

Fig. 3 Posterior view with needles on the left in position for L3 (L4 transverse process) and L4 (L5 transverse process) medial branch blocks. (Source: Fig. 11.3 in [34], with kind permission from Springer Science+Business Media)

technique has largely remained unchanged. The patient is placed in a prone position with a pillow under the abdomen to reduce lumbar lordosis and to position the lumbosacral junction away from the iliac crests. The $\mathrm{C}$-arm is then positioned over the lumbar spine with approximately $25^{\circ}-$ $30^{\circ}$ of oblique angulation to the axial plane. Traditionally, 10-cm Sluijter-Metha cannulae (SMK) with 5-mm active 
tips, ranging from 16 to 22 gauge, are then directed to the junction between the superior articulating process and transverse process at each level. The cannula is advanced superiorly to position the active tip along the course of the nerve. Testing is then performed with the patient awake, using sensory stimulation at $50 \mathrm{~Hz}$ at less than $0.5 \mathrm{~V}$ to produce pain or paresthesia in the area involved. Motor stimulation is then performed at $2 \mathrm{~Hz}$, usually at an output three times the necessary sensory stimulation level, to ensure proper placement and to avoid lesioning of spinal motor nerves.

The RFA lesion is then applied at a temperature of $60-90{ }^{\circ} \mathrm{C}$ for $60-90 \mathrm{~s}$. Traditional RFA for lumbar medial branch nerves is performed at $80{ }^{\circ} \mathrm{C}$ for $90 \mathrm{~s}$ after each level has been adequately anesthetized. The primary risk with conventional thermal RFA is inadvertent damage to motor nerves secondary to the thermocoagulation effect. Thermocoagulation of a spinal nerve root can also lead to deafferentation pain.

The proposed mechanism of action for RFA is two-fold. First, there is heat generation leading to thermo-coagulation and destruction of neural tissue [11]. It has been shown that $45^{\circ} \mathrm{C}$ is the threshold for damaging neural tissue [12]. RFA produces heat by current flow and not through heat transfer from the tip, which creates a well-demarcated lesion related to the gauge of the needle and length of the active tip. Secondly, there is formation of an electrical field in the surrounding tissue $[12,13]$. This mechanism is not entirely understood but thought to be secondary to neuromodulation [14]. It has been proposed that this occurs from inhibition of the excitatory c-fiber response or by modulation of dorsal horn cells [14].

Some studies have shown limited benefit between placebo and conventional thermal RFA for the treatment of facet-mediated LBP $[15,16]$. Leclaire et al. [15] showed no benefit for pain relief or improvement in functional disability beyond 4 weeks. Van Wijk et al. [16] showed improvement in VAS in both sham and radiofrequency groups and only favored radiofrequency in perceived effect. In carefully selected patients, however, there is good evidence to support the use of RFA [8, 17-19, 20•]. These studies have demonstrated reduction in pain for up to 12 months with conventional RFA. In a systematic literature review in 2013, Manchikanti et al. [8] concluded from 6 randomized controlled trials and 10 observational studies that the evidence is good for RFA for short- and long-term relief of facet-mediated LBP. In a similar systematic review in 2012 by Falco et al. [20•], their conclusions were similar with 11 randomized trials and 14 observational studies showing good evidence for both short- and longterm relief of pain from facet joint dysfunction. In another systematic review, Geurts et al. [17] examined randomized controlled trials and concluded that the evidence is moderate and in favor of RFA versus placebo. In a 2008 randomized double-blind trial with 40 participants, Nath et al. [18] showed statistically significant improvements in pain with RFA compared to placebo using strict inclusion criteria of three positive medial branch blocks. In a prospective study, Dreyfuss et al. [19] showed at least $90 \%$ pain relief was obtained in $60 \%$ of 15 patients included in the study at 12-month follow-up. Facet joint denervation should provide up to 6 months of pain relief based on two RCTs [21, 22].

\section{Pulsed Radiofrequency Ablation (pRFA)}

pRFA is carried out at similar output intensity as conventional RFA; however, it is performed in short pulses to reduce target temperature by allowing for cooling of tissues [13]. The procedure for pRFA is almost identical to conventional RFA, except that the current is typically carried out in 20-ms pulses every $0.5 \mathrm{~s}$ at a temperature that does not exceed $42^{\circ} \mathrm{C}$ [13]. Additionally, the cannula placement for lumbar pRFA requires that the active tip be directed along the course of the medial branch nerve, as the energy produced is released from the needle tip. In conventional RFA, the lesion produced is along the shaft of the needle surrounding the active tip.

As mentioned previously, the threshold for damaging neural tissue occurs at $45^{\circ} \mathrm{C}$ and pRFA avoids reaching this tissue temperature [11]. Even though higher temperatures are not reached, Slappendal showed RFA temperatures of 40 versus $67{ }^{\circ} \mathrm{C}$ provided identical pain relief when using RFA to treat the cervical dorsal root ganglion (DRG) [14]. The risk of damaging nerve structures is thus greatly reduced with pRFA due to lower tissue temperatures being maintained. The primary advantage of pRFA is to reduce lumbar facet-mediated pain while avoiding destruction of neural tissue from thermal injury. The mechanism of action for pRFA is theorized to be neuromodulation from the radiofrequency electrostatic field [13]. Van Zundert et al. [23, 24] showed induction of activity in cells in the dorsal horn of spinal cords of rats treated with pRFA, supporting the theory of neuromodulation. However, other studies have found contradictory findings that do not support this mechanism of action [25].

The use of pRFA for the treatment of facet-mediated pain has shown mixed results and remains controversial due to lack of evidence. For this reason, it is also not covered by most insurance carriers. While the evidence continues to grow, its limited use may be in part due to the limited number of studies evaluating pRFA for the treatment of facet-mediated pain. In a retrospective study, Mikeladze et al. [26] showed adequate pain relief lasting on average 4 months in $58 \%$ of patients treated for both lumbar and cervical facet-mediated pain with pRFA. In 
Table 1 Advantages and disadvantages of conventional thermal RFA versus pRFA

\begin{tabular}{|c|c|c|}
\hline & Advantages & Disadvantages \\
\hline Conventional & $\begin{array}{l}\text { Longer-lasting pain } \\
\text { relief } \\
\text { Covered by most } \\
\text { insurance carriers }\end{array}$ & $\begin{array}{l}\text { Increased procedural pain } \\
\text { Destruction of motor } \\
\text { nerves with improper } \\
\text { placement } \\
\text { Risk of deafferentation } \\
\text { pain }\end{array}$ \\
\hline Pulsed & $\begin{array}{l}\text { Less neuro-destructive } \\
\text { Less pain with procedure } \\
\text { Minimized tissue } \\
\text { destruction and tissue } \\
\text { overheating } \\
\text { Less risk of } \\
\text { deafferentation pain }\end{array}$ & $\begin{array}{l}\text { Shorter duration of relief } \\
\text { Procedure may need to be } \\
\text { repeated more } \\
\text { frequently } \\
\text { Higher cost to patient if } \\
\text { not covered by } \\
\text { insurance }\end{array}$ \\
\hline
\end{tabular}

another retrospective study, Lindner et al. [27] demonstrated that $72 \%$ of patients had favorable results at 4 months post-treatment with pRFA for lumbar facet pain. This study was limited, however, by small sample size and patients selected without prior surgery.

\section{Comparison of Conventional RFA Versus pRFA}

Few randomized controlled trials have been done directly comparing the effectiveness of conventional RFA versus pRFA in the treatment of facet joint dysfunction. Tekin et al. [28] showed positive results for both conventional and pRFA for short-term relief; however, at 6-month and 1-year follow-up, the pRFA group did not show lasting benefit. Knoll et al. [29] noted similar results in a 2008 study, with 3-month follow-up demonstrating greater improvement in pain relief with conventional RFA compared to the pRFA group. Table 1 provides a further breakdown of disadvantages and advantages between conventional versus pRFA.

\section{Conclusion}

We conclude that the evidence for effective pain relief for treatment of facet joint dysfunction with conventional RFA is good, while the use of pRFA is limited. In certain clinical circumstances, however, pRFA may be a viable alternative to conventional RFA. The primary indication for pRFA in lumbar spondylosis would be to avoid the unwanted side effects of conventional RFA, such as the denervation of the multifidus muscles, leading to atrophy and associated lumbar instability. This concept is controversial, as some studies have suggested the denervation to be insignificant [30]. However, the prior studies did not delineate whether patients had pre-existing instabilities, such as those with spondylolisthesis. Patients with facet arthropathy could already be at risk for this instability, especially if they underwent treatment with RFA bilaterally. There has yet to be research to explore whether pulsed RFA lesions lead to multifidus atrophy and whether this could be a potential benefit over conventional thermal RFA. In general, the use of pRFA for the treatment of lumbar facet-mediated pain has been found to have shorter duration and to be less effective than conventional RFA [31]. Given the paucity of evidence, further research is warranted in the arena of pRFA for the treatment of facet joint dysfunction.

\section{Compliance with Ethics Guidelines}

Conflict of Interest S. Pangarkar declare no conflicts of interest. M.L. Miedema declare no conflicts of interest.

Human and Animal Rights and Informed Consent All studies by the authors involving animal and/or human subjects were performed after approval by the appropriate institutional review boards. When required, written informed consent was obtained from all participants.

\section{References}

Papers of particular interest, published recently, have been highlighted as:

- Of importance

1. Rubin DI. Epidemiology and risk factors for spine pain. Neurol Clin. 2007;25(2):353-71.

2. Dreyer SJ, Dreyfuss PH. Low back pain and the zygapophysial (facet) joints. Arch Phys Med Rehabil. 1996;77(3):290-300.

3. DePalma MJ, Ketchum JM, Saullo T. What is the source of chronic low back pain and does age play a role? Pain Med. 2011;12(2):224-33.

4. Manchikanti L, Pampati V, Fellows B, Bakhit CE. Prevalence of lumbar facet joint pain in chronic low back pain. Pain Physician. 1999;2(3):59-64.

5. Manchikanti L, Singh V, Pampati V, Damron KS, Barnhill RC, Beyer $\mathrm{C}$, et al. Evaluation of the relative contributions of various structures in chronic low back pain. Pain Physician. 2001;4(4): 308-16.

6. Benzon HT. Essentials of pain medicine. 3rd ed. Philadelphia: Elsevier; 2011.

7. Fenton DS, Czervionke LF. Image-guided spine intervention. Philadelphia: Elsevier; 2003.

8. Manchikanti L, Abdi S, Atluri S, Benyamin RM, Boswell MV, Buenaventura RM, et al. An update of comprehensive evidencebased guidelines for interventional techniques in chronic spinal pain. Part II: guidance and recommendations. Pain Physician. 2013;16(2 Suppl):S49-283.

9. Shealy CN. Percutaneous radiofrequency denervation of spinal facets. Treatment for chronic back pain and sciatica. J Neurosurg. 1975;43(4):448-51.

10. Shealy CN. Facet denervation in the management of back and sciatic pain. Clin Orthop Relat Res. 1976;115:157-64.

11. Cosman ER Jr, Cosman ER Sr. Electric and thermal field effects in tissue around radiofrequency electrodes. Pain Med. 2005;6(6): 405-24. 
12. Smith HP, McWhorter JM, Challa VR. Radiofrequency neurolysis in a clinical model. Neuropathological correlation. J Neurosurg. 1981;55(2):246-53.

13. Ahadian FM. Pulsed radiofrequency neurotomy: advances in pain medicine. Curr Pain Headache Rep. 2004;8(1):34-40.

14. Slappendel R, Crul BJ, Braak GJ, Geurts JW, Booij LH, Voerman $\mathrm{VF}$, et al. The efficacy of radiofrequency lesioning of the cervical spinal dorsal root ganglion in a double blinded randomized study: no difference between 40 and $67{ }^{\circ} \mathrm{C}$ treatments. Pain. 1997;73(2):159-63.

15. Leclaire R, Fortin L, Lambert R, Bergeron YM, Rossignol M. Radiofrequency facet joint denervation in the treatment of low back pain: a placebo-controlled clinical trial to assess efficacy. Spine (Phila Pa 1976). 2001;26(13):1411-6; discussion 7.

16. Van Wijk RM, Geurts JW, Wynne HJ, Hammink E, Buskens E, Lousberg R, et al. Radiofrequency denervation of lumbar facet joints in the treatment of chronic low back pain: a randomized, double-blind, sham lesion-controlled trial. Clin J Pain. 2005;21(4):335-44.

17. Geurts JW, van Wijk RM, Stolker RJ, Groen GJ. Efficacy of radiofrequency procedures for the treatment of spinal pain: a systematic review of randomized clinical trials. Reg Anesth Pain Med. 2001;26(5):394-400.

18. Nath S, Nath CA, Pettersson K. 2008 Percutaneous lumbar zygapophysial (Facet) joint neurotomy using radiofrequency current, in the management of chronic low back pain: a randomized double-blind trial. Spine (Phila Pa 1976). 2008;33(12):1291-7; discussion 8 .

19. Dreyfuss P, Halbrook B, Pauza K, Joshi A, McLarty J, Bogduk N. Efficacy and validity of radiofrequency neurotomy for chronic lumbar zygapophysial joint pain. Spine (Phila $\mathrm{Pa}$ 1976). 2000;25(10):1270-7.

20. • Falco FJ, Manchikanti L, Datta S, Sehgal N, Geffert S, Onyewu $\mathrm{O}$, et al. An update of the effectiveness of therapeutic lumbar facet joint interventions. Pain Physician. 2012;15(6):E909-53. This article is a systemic review providing the latest update on the literature for facet joint interventions.

21. Gallagher J, Petriccione di Vadi PL, Wedley JR, et al. Radiofrequency facet joint denervation in the treatment of low back pain: a prospective controlled double-blind study to assess its efficacy. Pain Clin. 1994;7:193-8.

22. Van Kleef M, Barendse GAM, Kessels A, et al. Randomized trial of radiofrequency lumbar facet denervation for chronic low back pain. Spine. 1999;14:1937-42.

23. Van Zundert J, de Louw AJ, Joosten EA, Kessels AG, Honig W, Dederen PJ, et al. Pulsed and continuous radiofrequency current adjacent to the cervical dorsal root ganglion of the rat induces late cellular activity in the dorsal horn. Anesthesiology. 2005;102(1): 125-31.

24. Cahana A, Van Zundert J, Macrea L, van Kleef M, Sluijter M. Pulsed radiofrequency: current clinical and biological literature available. Pain Med. 2006;7(5):411-23.

25. Higuchi Y, Nashold BS, Sluijter M, et al. Exposure of the dorsal root ganglion in rats to pulsed radiofrequency currents activates dorsal horn lamina I and II neurons. Neurosurgery. 2002;50: $850-5$.

26. Mikeladze G, Espinal R, Finnegan R, Routon J, Martin D. Pulsed radiofrequency application in treatment of chronic zygapophyseal joint pain. Spine J. 2003;3(5):360-2.

27. Lindner R, Sluijter ME, Schleinzer W. Pulsed radiofrequency treatment of the lumbar medial branch for facet pain: a retrospective analysis. Pain Med. 2006;7(5):435-9.

28. Tekin I, Mirzai H, Ok G, Erbuyun K, Vatansever D. A comparison of conventional and pulsed radiofrequency denervation in the treatment of chronic facet joint pain. Clin J Pain. 2007;23(6): 524-9.

29. Knoll HR, Kim D, Danic MJ, Sankey SS, Gariwala M, Brown M. A randomized, double-blind, prospective study comparing the efficacy of continuous versus pulsed radiofrequency in the treatment of lumbar facet syndrome. J Clin Anesth. 2008;20(7): 534-7.

30. Dreyfuss P, Stout A, Aprill C, Pollei S, Johnson B, Bogduk N. The significance of multifidus atrophy after successful radiofrequency neurotomy for low back pain. PM R. 2009;1(8):719-22.

31. Chua NH, Vissers KC, Sluijter ME. Pulsed radiofrequency treatment in interventional pain management: mechanisms and potential indications-a review. Acta Neurochir (Wien). 2011;153(4): 763-71.

32. Binder DS, et al. The provocative lumbar facet joint. Curr Rev Musculoskelet Med. 2009;2(1):15-24.

33. Panchal SJ. Facet injections and radiofrequency denervation, chap. 36. In: Deer TR, Leong MS, Buvanendran A, Gordin V, Kim PS, Panchal SJ, Ray AL, editors. Comprehensive treatment of chronic pain by medical, interventional, and integrative approaches. The American academy of pain medicine textbook on patient management. Springer; 2013. p. 371-80.

34. Wallace MS, Moeller-Bertram T. Facet joint and epidural injections, chap. 11. In: Ozgur B, Benzel E, Garfin S, editors. Minimally invasive spine surgery. A practical guide to anatomy and techniques. Springer; 2009. p. 99-104. 